\title{
Traditional Kehr's sign: Left shoulder pain related to splenic abscess
}

\author{
Geleneksel Kehr bulgusu: Splenik apseye bağlı sol omuz ağrıs1
}

\author{
Seçgin SÖYÜNCÜ, Fırat BEKTAŞ, Yıldıray ÇETE
}

Kehr's sign was originally described by the German surgeon Hans Kehr (1862-1916). It is a classical example of referred pain: irritation of the diaphragm is signaled by the phrenic nerve as pain in the area above the clavicle. We present a case of a 21-year-old woman admitted to the emergency department with the chief complaint of left shoulder pain related to splenic abscess.

Key Words: Kehr's sign; referred pain; splenic abscess.
Kehr bulgusu ilk olarak Alman cerrah Hans Kehr (18621916) tarafından tanımlanmıştır. Kehr bulgusu yansıyan ağrının klasik bir örneğidir. Diyafram irritasyonu klavikulanın üzerindeki bir bölgede ağrı duyusu olarak frenik sinir tarafindan oluşturulur. Acil servise sol omuz ağrısı nedeniyle başvuran ve splenik apse tanısı konulan 21 yaşındaki kadın olguyu sunduk.

Anahtar Sözcükler: Kehr işareti; yansıyan ağrı; dalak apsesi.
Kehr's sign was originally described by the German surgeon Hans Kehr (1862-1916). ${ }^{[1]}$ It is a classical example of referred pain: irritation of the diaphragm is signaled by the phrenic nerve as pain in the area above the clavicle.

We present a case of a 21-year-old woman admitted to the emergency department with the chief complaint of left shoulder pain related to splenic abscess.

\section{CASE REPORT}

A 21-year-old woman presented to the emergency department (ED) with the chief complaint of left shoulder pain. The pain had lasted for one week without any other complaint. Her medical history revealed that she had been operated for achalasia one month ago. Her vital signs were as follows: blood pressure $125 / 75 \mathrm{mmHg}$, pulse rate 96 beats/minute, respiratory rate 18 breaths/minute, axillary temperature $37^{\circ} \mathrm{C}$, and $\mathrm{SPO}_{2} 98 \%$ by pulse-oximeter in room air. Left shoulder joint movements and range of motion were fully normal and painless in the physical examination. Neurovascular findings of the upper extremity were intact. Abdominal and other physical examinations were normal. Her white blood cell count was $18.4 \mathrm{x}$ $10^{3} / \mathrm{mm}^{3}\left(4.8-10.8 \times 10^{3} / \mathrm{mm}^{3}\right)$. Since she had been operated recently, the pain was thought to be Kehr's sign, and an abdominal computed tomography (CT) was ordered. As can be seen in the abdominal tomography, the cause of Kehr's sign in this patient was the splenic abscess (Fig. 1). The patient was hospitalized and splenectomy was performed under general anesthesia. She was discharged from the hospital 10 days postoperatively, during which she was tolerating a full liquid diet and had resumed bowel function.

\section{DISCUSSION}

The review of the literature showed a number of case reports mentioning "Kehr's sign". ${ }^{[2,3]}$ One report was about splenic rupture and the other was phrenic artery rupture. Kehr's sign due to splenic abscess was not reported in the past articles. Although splenic abscess is rare, it has a high mortality rate if there is a delay in diagnosis and treatment. The clinical triad of splenic abscess is fever, left upper abdominal pain and 


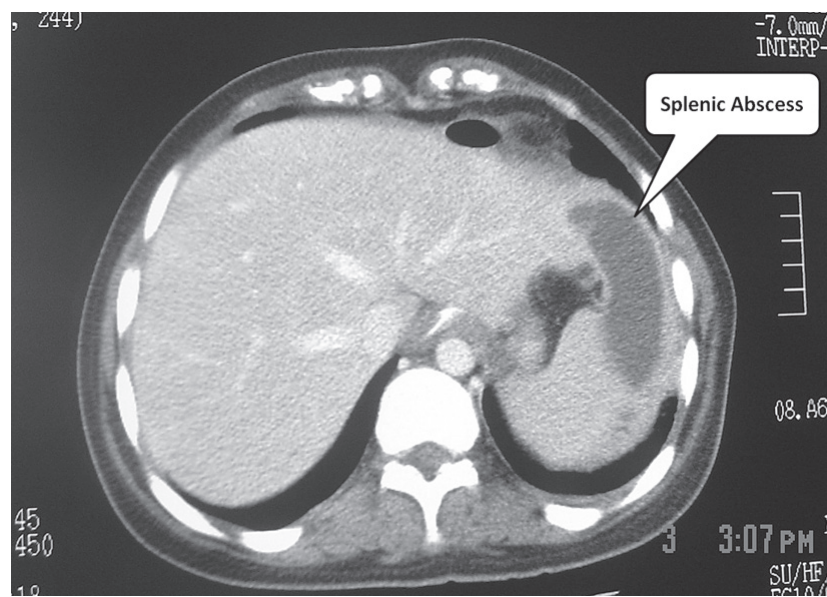

Fig. 1. Abdominal tomography demonstrates splenic abscess causing Kehr's sign.

leukocytosis. With the combination of the clinical triad and imaging findings, the diagnostic rate increased to $86.7 \%{ }^{[4]}$ The only positive component in our patient from this triad was the leukocytosis, and she had no left abdominal pain or fever. The nonspecific clinical presentation as described in our patient should be thoroughly investigated, and CT, the most sensitive diagnostic tool, should be used whenever splenic abscess is suspected. ${ }^{[4]}$
Since the technologic development of new devices and diagnostic modalities are growing rapidly, the detailed medical history and physical examination have lessened in importance. Many physicians waive a detailed examination and conduct many more laboratory tests and imaging studies. The responsibility of caring for many different kinds of patients at the same time and overcrowding in the EDs have given rise to the use of more diagnostic modalities despite indications, and this approach decreases cost-effectiveness. The art of medicine and of traditional physical processes should never be forgotten as a result of technologic development, and every physician should teach this art skillfully to young practitioners.

\section{REFERENCES}

1. Russell RCG. Spleen. In: Mann CV, Russell RCG, editors. Bailey and Loves' short practice of surgery. London: Chapman \& Hall; 1992. p. 1038.

2. Sutton CD, Marshall LJ, White SA, Berry DP, Dennison AR. Kehr's sign - a rare cause: spontaneous phrenic artery rupture. ANZ J Surg 2002;72:913-4. CrossRef

3. Lowenfels AB. Kehr's sign-a neglected aid in rupture of the spleen. N Engl J Med 1966;274:1019. CrossRef

4. Ng KK, Lee TY, Wan YL, Tan CF, Lui KW, Cheung YC, et al. Splenic abscess: diagnosis and management. Hepatogastroenterology 2002;49:567-71. 